\title{
Effectiveness and Teachers' Confidence in E-Learning Usage in Teaching and Learning English during Covid 19 Pandemic at a University
}

\author{
English Education Department, FKIP, Universitas Jambi, Jambi, Indonesia \\ *Corresponding author. Email: hadiyanto@unja.ac.id
}

Hadiyanto*, Dedy Kurniawan, Mariza Juwita

\begin{abstract}
Covid-19 pandemic threat had forced the Ministry of Indonesia Education and Culture to take a policy of changing the process of teaching and learning from classroom to online learning space. However, the emergency policy of the use of e-learning for the full learning process possibly hinders the effectiveness of the learning process and goal of learning. Responding to the issues, this study aims to investigate teachers' confidence and perception of the effectiveness of teaching English from General through e-learning. Thirty-one of English teachers at a university participated in the online survey. A questionnaire was used to investigate the teachers' confidence and perception toward the effectiveness of e-learning usage for teaching General English. The study reveals that the majority of English teachers (15) are averagely confident, 14 English teachers are highly confident to use e-learning for teaching and learning General English, and 2 of teachers are at low confidence. The findings also reveal that majority (21) teachers perceive that the effectiveness of e-learning usage for teaching General English is at an average level, and 3 of teachers perceive at low effectiveness, and only 7 of respondents perceive the effectiveness of e-learning usage at a high level. In conclusion, the English teachers are not confident enough to use e-learning for teaching and learning English for General, and the usage of e-learning is not very effective for obtaining course objectives. It is recommended that policy makers at the university level provide teachers with more training on using e-learning for effective teaching and learning English.
\end{abstract}

Keywords: English for general communication, online learning, digital era, English instruction

\section{INTRODUCTION}

E-learning is an online learning application that uses internet technology to connect students and teachers in order to do the teaching and learning process. In elearning, the instructor does not simply post learning materials on e-learning to be accessed by students, but teachers also need to pay attention to learning design, learning strategy and method, learning evaluations, establish communication, collaborate, and manage other aspects of learning (Snow, 2015). Furthermore, elearning provides virtual interactive tools and features that are expected to solve the problem such as of time constrains, face to face meetings replacement, class shortages, and busy schedules for teachers and students. Students will be able to develop their English even though outside of the curricular classroom. They can study anywhere and anytime outside the classroom and work independently.
General English course is a compulsory subject for all students at the present University or location of this conducted research. All English teachers are involved in English education in teaching general English courses. This situation has impacts on the shortage of English teaching staff, congested lecture time, a limited number of rooms, overcrowded lecture schedules, and constrain the mobility of English teachers in teaching across study programs. Out of the challenges, the heaviest challenge is now coming. It is the Covid-19 pandemic that makes all universities have to change learning mode from faceto-face classroom onto e-learning or online learning.

The application of e-learning for teaching and learning English has not been optimally implemented. So far, it is only used as a source of teaching and learning material. It is assumed that not all teachers are capable of creating teaching materials on the internet, interactive forums in the virtual world, or exercises 
using the e-learning system. Besides the results of the observation, the interviews conducted with a few teachers revealed that they are not so confident to use some features and supportive application of e-learning for teaching English. Therefore, the teachers' confidence in their ability on E-learning usage is a crucial thing to be paid attention to before the policy of online learning is fully implemented such as in the covid-19 pandemic situation. The effectiveness of elearning usage for teaching general English is also an urgent matter to be investigated for the possibility of a fully online course on general English teaching and learning after the covid-19 pandemics.

\section{LITERATURE REVIEW}

\section{E-learning and Teaching English}

The use of information technology, specifically elearning required not only skilful educators in using information technology and designing teaching materials, but also a good instructional design that must obtain learning goals effectively. In instructional design, teachers have to think about how to deliver the knowledge and skills of a course (Al-Maqtri, 2014). Available features, tools, and capacity should be used optimally. Learning strategy and learning methods can be implemented in e-learning by utilizing selective appropriate features, tools, and applications on elearning. Furthermore, in the implementation of elearning, there are evaluation stages which are used to revise or adjust the previous stages. Instructional design is a dynamic process that can be changed according to that accepted information and evaluation. It aims to improve the learning results of learners so learning goals can be achieved (Esgi, 2013).

E-learning is a learning process that involves the use of electronic equipment in creating, fostering, conveying, assessing, and facilitating the learning process with students as an interactive centre, anytime and anywhere (Hadiyanto, 2019a; Witherspoon, 2011). The basic criteria for online learning are network, online and learning materials, online evaluation according to learning stages, and a focus on broad learning (Bartley, 2004).

Some principles of e-learning usage should be taken into account prior to using e-learning for teaching and learning English (Hadiyanto, 2019b). Referring to Mayer (2009), there are six of eight e-learning principles that are needed to be applied in designing teaching general English. The six principles concern the elements of the media in e-learning which is the basis for developing media in e-learning. For conveying learning, a combination of texts, graphics, animation, and sound is needed in order to make learning being more effective (Mayer, 2009). The six principles are (1) Spatial Contiguity Principle: the main focus of this principle is the presentation of multimedia material will be more interesting and effective when linked words and pictures are presented contiguously to each other. As Rodrigues and Vethamani (2015) stated that if presenting words and pictures are close to each other, it will be easier for students to learn to capture and save message memory. This principle means that a topic of a subject main material is attached in E-learning which is textual presentation necessarily supported by picture, illustration, graphic, and animation to optimizing content delivery to the students. (2) the principle of proximity to time: the main focus of this principle is to put words and pictures together. The implication of this principle for e-learning is by concurrently serving the text position and relevant graphics so it's easily understood by users; (3) Modality Principle: This principle explains that the use of animation and narrative can improve learning activities. The implication of this principle for e-learning is by presenting videos in e-learning because multimedia messages from videos are spoken text thus will be easier to understand; (4) Redundancy Principle: This principle explains that learners can learn better from animation and narration than animation only. The implication of this principle for e-learning is by presenting material with animation and narration in video form; (5) Coherence Principles: this principle explains that the use of unrelated pictures, words, and sounds can destruct learning activities. The material presented will be more defective on the use of unrelated words, sound, and images; (6) The principle of individual differences: This principle explains that the effect of the design is stronger for low-knowledge students than for high-level students. The six principles above are appropriate to be used in teaching and learning English for all skills: speaking, listening, reading, and writing.

Language learning concept using e-learning allows students to improve their language skills, speaking, listening. Reading and writing. Such as the concept of elearning provides some features that can be used by teachers to manage student activities in language learning. Since face-to-face meeting has limited hours, continuing learning from classroom to the virtual classroom such e-learning is a good way to add more hours of learning outside the classroom (Soliman, 2014). The number of learning hours will impact second language learners to be more successful to develop their language skills (Rodrigues \& Vethamani, 2015). Wichadee (2017) believes today's learning, conventional learning, must be complemented by the use of information technology to boost students learning activities. 
Table 1. Mean interpretation of soft skills practices

\begin{tabular}{|l|l|}
\hline \multicolumn{1}{|c|}{ Mean Score } & \multicolumn{1}{c|}{ Level } \\
\hline $1.00-1.80$ & Very Low \\
\hline $1.81-2.60$ & Low \\
\hline $2.61-3.40$ & Medium \\
\hline $3.41-4.20$ & High \\
\hline $4.21-5.00$ & Very High \\
\hline
\end{tabular}

\section{METHODS}

The target population of this study was general English teachers at a major university in Jambi Province. The total sample used in the study was 31 teachers out of 38 general English courses. A set of questionnaires with 5-point Likert scale responses was developed to measure teachers' perception of their confidence and effectiveness of e-learning usage. Respondents' response for the confidence of e-learning usage for teaching and learning general English was by choosing 1 out of 5 alternative answers; very unconfident, unconfident, average, confidence and very confidence, while for the effectiveness of e-learning usage was by choosing one of five following answers; $1=$ Strongly Infective, 2=Ineffective, 3=Average, 4=Effective, 5=strongly effective. Application of Online SurveyMonkey was used in data collection. A reliability analysis demonstrated a high Cronbach alpha coefficient $(>0.7)$ and corrected-item correlation $(>.300)$ for both constructs; teachers' confidence and effectiveness of elearning usage for teaching and learning English (Pallant, 2011). Descriptive statistics were applied to report the research findings. The mean score of the respondents' response from 1 to 5 scales was interpreted in five levels of interpretation, as shown in Table 1.

As Table 1 shows, a mean score between 1.00 and 2.33 indicates a low level of soft skills, a mean score between 2.34 and 3.66 a medium level, and a mean score between 3.67 and 5.00 a high level of soft skills.

\section{FINDINGS AND DISCUSSION}

Descriptive statistics were used to portray teachers' confidence and effectiveness of general English teaching and learning through e-learning. As displayed in Table 2, teachers are confident (3.50) for using elearning for teaching and learning general English. However, teachers perceive the effectiveness of elearning usage for teaching general English at a medium level $(3,20)$. All components of effectiveness are at a medium level.

Table 3 shows teachers' confidence in using elearning in teaching and learning English for General. As reported above, overall teachers' confidence was at a high level (3.50). Further analysis of teachers' confidence shows that teachers perceive their confidence in terms of statement E3, E4, E6, and E7 to E14 were at a high level. This means that teachers were highly confident in using e-learning for teaching general English on those aspects. However, teachers rated three statements at medium level: E1, E2 and E5. In another way to say that teachers' ability in creating an online course orientation, writing measurable objectives, and creating instructional videos are not satisfied.

English teachers perceived the overall effectiveness of teaching general English at a medium level (3.31). Effectiveness related to opportunities for students to practice the four skills in overall was medium level (3.29). Looking at each skill, opportunities for students to practice online English writing skills were at a high level (mean 3.51). However, opportunities for students to practice online reading (3.55), listening (3.38) and speaking (2.96) skills were at medium level.

English teachers perceived effectiveness relate to interactive sessions between teachers and students was at a medium level (3.16). Teachers also perceived the effectiveness of interactive sessions between teachers and students for all English skills was at a medium level. Effectiveness in delivering course content based on the topic in every session was at a medium level (3.29). The teachers perceived delivering course content based on the topic in every session for writing skills was at a high level (3.50). However, three other skills; reading, listening, and speaking were rated at a medium level of effectiveness in terms of delivering course content based on the topic in every session.

The finding also shows that the effectiveness of measuring students' English performance was at a medium level (3.29). The use of e-learning for measuring students' reading (3.38), listening (3.32) and speaking performance in English (2.96) was at a medium level. However, teachers perceived that $\mathrm{e}$ learning was a highly effective form to measure students writing performance (3.51).

Table 2. Overall mean and level of soft skills practices

\begin{tabular}{|l|l|l|l|}
\hline \multicolumn{1}{|c|}{ Variables } & \multicolumn{1}{|c|}{ Mean } & S.td & \multicolumn{1}{|c|}{ Level } \\
\hline Confidence & 3.50 & .711 & $\begin{array}{l}\text { Highly } \\
\text { Confidence }\end{array}$ \\
\hline Effectiveness & 3.30 & .691 & Medium \\
\hline $\begin{array}{l}\text { Opportunities for students to } \\
\text { practice online }\end{array}$ & 3.16 & .745 & Medium \\
\hline $\begin{array}{l}\text { Interactive sessions between } \\
\text { teacher and students }\end{array}$ & 3.29 & .748 & Medium \\
\hline $\begin{array}{l}\text { Delivering course content } \\
\text { based on the topic in every } \\
\text { session }\end{array}$ & 3.06 & .816 & Medium \\
\hline $\begin{array}{l}\text { Measuring students' English } \\
\text { performance }\end{array}$ & 3.20 & .656 & Medium \\
\hline $\begin{array}{l}\text { The overall effectiveness of } \\
\text { teaching general English }\end{array}$ & & & \\
\hline
\end{tabular}


Table 3. Mean and level of teachers' confidence in using e-learning in teaching general English

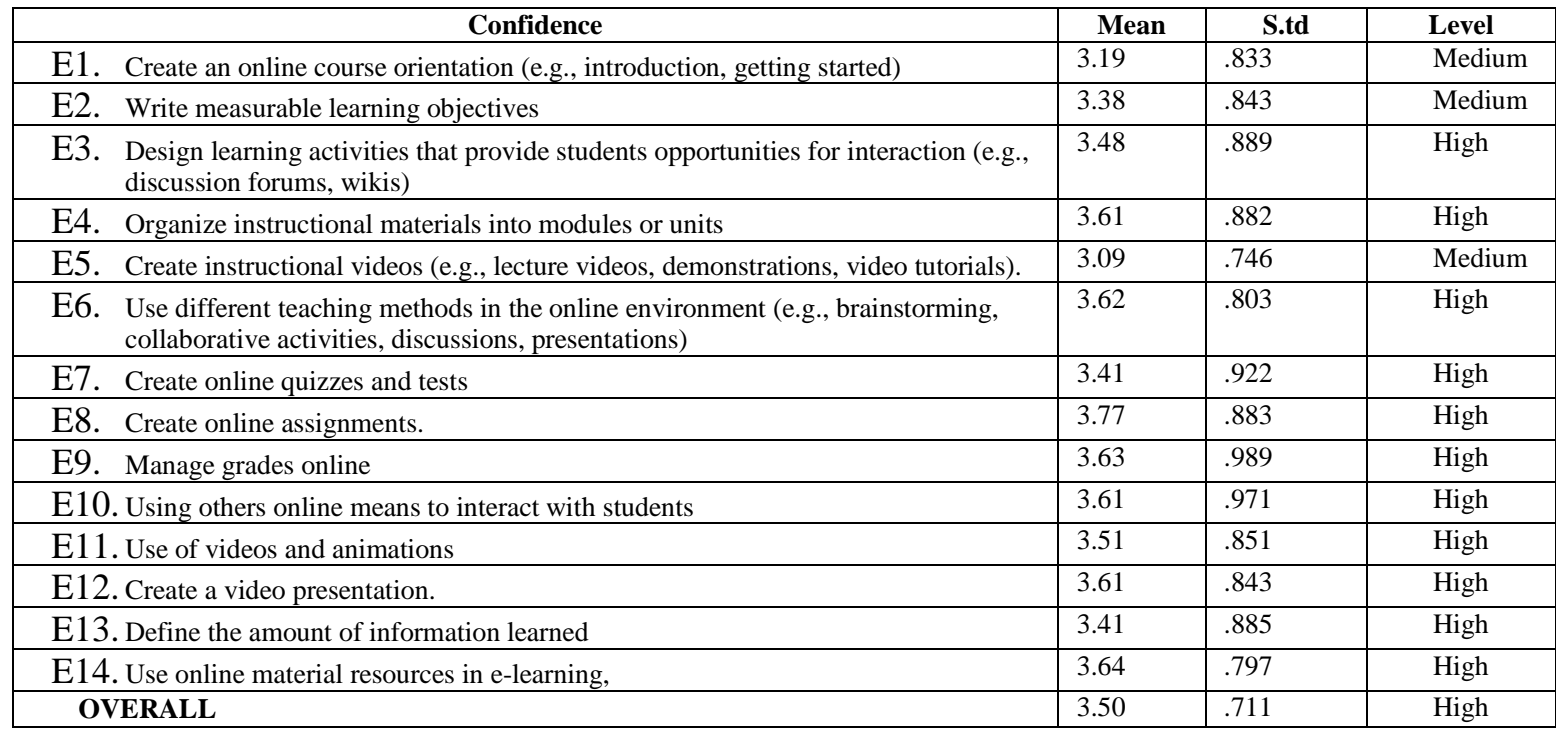

The result of the present study reveals that teachers are confident at a high level of using e-learning for teaching and learning general English (Table 4). This means that teachers are able to manage general English learning through e-learning. However, the findings also implied that teachers are not very competent to use elearning for teaching and learning English, because there no statement that is rated at a very high level of the mean score of confidence level. Furthermore, teachers were highly confident in using e-learning for teaching general English in aspects of designing learning activities, organizing instructional materials, using different teaching methods, creating online quizzes and tests, creating online assignments., managing grades online, using others online means to interact students, using videos and animations, creating video presentation, defining the amount of information learned, and using online material resources.

On other hand, teachers' ability in creating an online course orientation, writing measurable objectives, and creating instructional videos are not satisfied. The findings are in line with Hadiyanto et al. (2013). It was found that teachers were ready at a medium level of using ICT for English instruction. In short, teachers' ability was not enough to fully handle learning via elearning. On contrary, now it is a situation when we have to apply full online learning for the teaching and learning process due to covid-19 pandemic. Policy makers were suggested to provide some training for teachers to boost teachers' competence in using elearning until at a very confident level.
Table 4. Mean and level of teachers' effectiveness in teaching general English

\begin{tabular}{|l|l|l|l|}
\hline $\begin{array}{l}\text { Effectiveness of Teaching English } \\
\text { Skills }\end{array}$ & Mean & S.td & Level \\
\hline Opportunities for students to practice online & \\
\hline Reading & 3.35 & .877 & Medium \\
\hline Writing & 3.51 & .811 & High \\
\hline Listening & 3.38 & .989 & Medium \\
\hline Speaking & 2.96 & .752 & Medium \\
\hline Overall & 3.31 & .691 & Medium \\
\hline Interactive sessions between teacher and students \\
\hline Reading & 3.03 & .874 & Medium \\
\hline Writing & 3.38 & .817 & Medium \\
\hline Listening & 3.16 & 1.00 & Medium \\
\hline Speaking & 3.06 & .813 & Medium \\
\hline Overall & 3.16 & .745 & Medium \\
\hline Delivering course content based on the topic in every session \\
\hline Reading & 3.38 & .954 & Medium \\
\hline Writing & 3.50 & .891 & High \\
\hline Listening & 3.32 & .871 & Medium \\
\hline Speaking & 2.96 & .836 & Medium \\
\hline Overall & 3.29 & .748 & Medium \\
\hline Measuring students' English performance \\
\hline Reading & 3.38 & .954 & Medium \\
\hline Writing & 3.51 & .851 & High \\
\hline Listening & 3.32 & .871 & Medium \\
\hline Speaking & 2.95 & .836 & Medium \\
\hline $\begin{array}{l}\text { Overall effectiveness of teaching } \\
\text { general English }\end{array}$ & $\mathbf{3 . 2 9}$ & $\mathbf{. 7 4 8}$ & Medium \\
\hline & & & \\
\hline & \multicolumn{3}{|l}{} \\
\hline
\end{tabular}

Teachers reveal that the effectiveness of e-learning usage for teaching general English is at a medium level. In every aspect of effectiveness, teachers also claim that e-learning is only effective for online writing but not very effective for giving opportunities for students to practice reading, speaking, and listening skills. Elearning is perceived by the teachers as not effective for accommodating interactive sessions between teachers and students for all general English skills. E-learning is considered effective in delivering course content based 
on the topic in every session for writing skills but less effective for reading, speaking and listening. Last but not least, measuring students' English performance through e-learning was effective for writing skills but not for the other three skills: reading, speaking, and listening. Theoretically, the level of effectiveness is correlated with the teachers' confidence. That is why that teachers' competence to use e-learning and other supportive application must be improved in order to impact on the effectiveness of e-learning usage for developing students' English skills (Soliman, 2014; Wichadee, 2017).

Finally, the results of this research are expected to provide information and innovation in e-learning usage in developing learning general English both for students and teachers. For whoever is responsible for organizing the usage of e-learning, it is needed to prepare teachers with enough knowledge and skills. This action is important for further implementation of the learning program based on fully online learning, thus the online learning process at a University can run effectively or close to conventional learning standards.

\section{CONCLUSION}

The study had proved that the General English teachers at a major University in Jambi were not at the top level of confidence to use e-learning for teaching English for General. Teachers also perceived that the usage of e-learning is not very effective for teaching General English. It is recommended that policy makers at the University level need to provide teachers with training to enhance teachers' IT knowledge and skills particularly on using e-learning in an effective way in teaching General English. The result of the study informs teachers how to design General English teaching and learning through e-learning in order to obtain a maximal outcome of learning. Theoretically, the study strengthens existing theories and concepts of confidence and effectiveness of using e-learning for general English teaching. Last but not least, the study informs policy makers to improve teacher's confidence in order to achieve a very satisfying outcome of learning. For instance, policy maker can provide essential training related to e-learning usage for teaching General English at the present University.

\section{REFERENCES}

Al-Maqtri, M. A. T. (2014). How effective is e-learning in teaching English?: A case study. Journal of
Education and Human Development, 3(2), 647669.

Bartley, M. (2004). Health inequality: An introduction to theories, concepts and methods. Cambridge: Polity Press.

Esgi, N. (2013). Comparison of effects of e-learning types designed. International Journal of Academic Research, 5(5), 443-450. http://dx.doi.org/10.7813/2075-4124.2013/5-5/B.69

Hadiyanto. (2019a). The EFL students' 21 st century skill practices through e-learning activities. IRJE, 3(2), 2580-5711.

Hadiyanto, H. (2019b). Enhancing students' core competencies by applying blended cooperative elearning (BCeL). Teaching and Learning Process. 253 (AES 2018), 169-173. https://doi.org/10.2991/aes-18.2019.40

Hadiyanto, Makmur, Mukminin, A., Hidayat, M., \& Failasofah. (2013). Teaching in a digital era: English lecturers' readiness toward the internet use in teaching and learning at selected higher education institutions in Indonesia. Asia-Pacific Collaborative Education Journal, 9(2), 113-124. Retrieved

from http://apcj.alcob.org/journal/article.php?code=2132 $7 \&$ ckattempt $=1$

Snow, M. A. (2015). Effective eLearning and eTeaching-A Theoretical Model. In E-LearningInstructional Design, Organizational Strategy and Management. Boyka Gradinarova, Intech Open. DOI: $10.5772 / 60578$.

Mayer, R. E. (2009). Multimedia learning (2nd ed.). New York: Cambridge University Press.

Pallant, J. (2011). A step by step guide to data analysis using SPSS for Windows (version 12). Buckingham, Philadelphia: Open University Press.

Rodrigues, P., \& Vethamani, M. (2015). The impact of blended learning in the development of speaking skill. Journal of Interdisclipnary Research in Education (JIRE), 5(1), 43-67.

Soliman, N. A. (2014). Using E-learning to develop EFL students' language skills and activate their independent learning. Creative Education, 2014, 5(10), 752-757.

Wichadee, S. (2017). A development of the blended learning model using Edmodo for maximizing students' oral proficiency and motivation. International Journal of Emerging Technologies in Learning (iJET), 12(02), 137-154. 